\section{Reactor judged not so fast}

\section{London}

ANY lingering hopes held by the UK Atomic Energy Authority (UKAEA) for a revival of Britain's flagging fast-breeder reactor programme were dashed last week by the publication of a report from an allparty House of Commons committee. The report agrees with the government's decision to end support for the prototype fast reactor at Dounreay, Scotland, from 1994 and concludes that continuing British investment in a European Fast Reactor (EFR) after construction begins in 1997 is unlikely to be worthwhile.

Fast reactor research has consumed $£ 4,000$ million (in 1988 money) of government funds since 1954. When development began, fast reactors made sense because it was thought that uranium fuel would eventually be in short supply. Fastbreeder reactors can extract 60 times more energy from a quantity of uranium than conventional thermal reactors. But there is still no shortage of uranium.

The energy select committee rejects claims from the old Central Electricity Generating Board (CEGB) that fast reactors are needed as part of Britain's strategic energy planning. Major expenditure on fast reactors can be justified only if there is "a potential economic case", and calculation of the likely future supply of uranium show that it is very unlikely that fast reactors will become economic before 2020 . Further development should wait, the committee says, because of the risks of designs "becoming obsolete" before they are required commercially.

Former energy secretary Cecil Parkinson decided in 1988 that funding for the UKAEA Dounreay fast reactor should end after 1994. But Britain is still involved

\section{UFC funds deep-sea}

\section{centre}

\section{London}

The UK Universities Funding Council (UFC) has agreed to provide $£ 10$ million for a new centre for deep-sea oceanography in Southampton. The centre will open in 1994 at an estimated cost of $£ 43$ million, mostly supplied through the Natural Environ-ment Research Council (NERC). The UFC money is to allow researchers from the University of Southampton to move to the centre and work with NERC scientists.

The centre will have an important role in climate change research, hosting the UK contribution to the World Ocean Circulation Experiment, a large project investigating the relationship between oceans and climate - a major uncertainty in current climate models.

Peter Aldhous with France and West Germany in a plan to begin building the European Fast Reactor in 1997.

British experience with the Dounreay reactor is valuable to the project, but the United Kingdom is a junior partner financally, contributing some $£ 10$ million a year - about 15 per cent of the total. The remainder of the research and development costs are divided roughly equally between France and West Germany. But the UK contribution is expected to rise to almost $£ 350$ million in each of the two peak years of construction.

The energy committee concludes that this investment should be reviewed in 1993 and 1997, and seems at present to be unnecessary. The CEGB and UKAEA argued that British withdrawal from the EFR would wreck the collaboration, but the committee believes that France will probably continue with fast reactor development in any event. Jean Leduc, from Novatome, a French company which builds nuclear power stations, says fast

\section{Munich}

LiKE a person who has recently given up smoking, non-nuclear Austria is trying to persuade its neighbours that they too should give up nuclear power, for their own sake and for the sake of those around them.

Concern about the safety of some of Czechoslovakia's oldest power plants has provoked Austria's latest antinuclear crusade. Last week, Austria offered to sponsor an inspection of the two oldest reactor blocks at Bohunice, in Slovakia near the Austrian border, and to deliver electricity valued at 10 million schillings (about $\$ 830,000$ ) a day for up to 10 days during which the plant will be shut down.

Austria chose to abandon its own nuclear programme in 1987, but construction and operation of nuclear plants in three neighbouring states -- Czechoslovakia, Hungary and Yugoslavia - has rolled merrily along (see Nature 346, 98; 12 July 1990). Although the Czechoslovak government ultimately agreed to allow Austrian experts to join in a safety inspecti of Bohunice by 10 August, new Czechoslovak Environment Minister Josef Vavrousek says that "there is a 99 per cent chance" that such an inspection would find the reactors safe. Austrian Environment Minister Marilies Flemming disagrees, saying that if even a fraction of the reports she has heard about Bohunice are true, it must be shut down immediately.

Flemming will travel to Hungary next week, where a spokeswoman said she reactor development is "more urgent" in France than the United Kingdom. France already relies heavily on nuclear generated electricity, and has a generation of pressurized water reactors that must be replaced between 2010 and 2020. Leduc says the EFR programme is organized to produce a commercial design by this time.

In the future, concern over global warming may change energy policy and favour power plants that produce little carbon dioxide. But the committee did not feel these considerations would affect the economic viability of fast reactors. Renewable forms of electricity generation, such as wind, wave and tidal power, are in the same situation as fast reactors "technically proven but not [yet] commercially viable" - and other forms of nuclear electricity generation, notably pressurized water reactors, share the advanatage that they do not produce carbon dioxide but are cheaper, unless the price of uranium increases substantially.

The report says that large-scale research and development projects should be kept under "close and continuous review".

Peter Aidhous

\title{
Kicking the habit
}

would urge the Hungarians to resume construction of the huge Nagymaros hydroeletric dam project, which the Hungarian government stopped last year in order to protect the Danube and surrounding areas. Electricity generated by the project would provide an alternative to that from nuclear power plants. After that, she will try to persuade Yugoslavia to shut the Krsko nuclear plant, which is in Slovenia, also not far from Austria.

Beyond the goodwill gesture of replacing lost power for a few days, Austria has made few offers to help Czechoslovakia finance the building of new power stations. The Austrian government estimates that it would cost $\$ 16,000$ million just to bring existing Czechoslovak power stations up to Western standards. Austrian ministers met Western European leaders in Salzburg last week to try to persuade them to set up an "Energy Marshall Plan" for Eastern Europe.

A spokesman for the International Atomic Energy Agency (IAEA) in Vienna, which will carry out a limited safety inspection of its own in October, said it takes the problems with reactors of the type found in Bohunice (VVER 440-V 230) "very seriously". Such reactors are also found in Bulgaria, the Soviet Union and also in East Germany, where they were judged unsafe and ordered shut earlier this year. IAEA spokesman David Kyd said it would try to "get everyone around a table" to discuss the future of these reactors. 